\title{
A Case of Pulmonary Involvement in Rheumatoid Arthritis Mimicking Metastatic Lung Cancer
}

\author{
Nezihe Çiftaslan Gökşenoğlu, ${ }^{1}$ Emine Aksoy, ${ }^{1}$ Fatma Tokgöz Akyil, \\ Yasemin Bodur, ${ }^{2}$ Tülin Sevim'
}

'Department of Chest Diseases,

Süreyyapaşa Chest Diseases and Chest Surgery Training and Research Hospital, İstanbul, Turkey ${ }^{2}$ Department of Chest Diseases, Diyarbakır Gazi Yaşargil Training and Research Hospital, Diyarbakır, Turkey

Submitted: 05.10.2016 Accepted: 15.11.2016

Correspondence: Nezihe Çiftaslan Gökşenoğlu, Süreyyapaşa Göğ. Hast. ve Göğ. Cer. Eğit. ve Araşt. Hast., Göğüs Hast. Kliniği, İstanbul, Turkey

E-mail:ncftsIn@hotmail.com

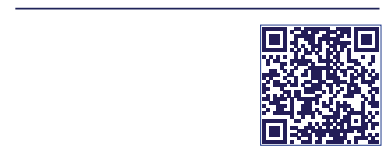

Keywords: Anti-CCP; bilateral nodul; pleural effusion; rheumatoid arthritis.

\begin{abstract}
Rheumatoid arthritis (RA), as a systemic autoimmune disease, frequently features pulmonary involvement. A 58-year-old woman was examined due to shortness of breath, stomach ache, and arthralgia. Pleural effusion and bilateral pulmonary nodules were observed on chest $\mathrm{X}$-ray, and patient was sent to our hospital with initial diagnosis of metastatic lung cancer. Creactive protein level and sedimentation rate test results were elevated. Thoracentesis was performed, and pleural effusion was found to be exudative. Low glucose and high adenosine deaminase and lactate dehydrogenase levels were detected. Blood and pleural fluid rheumatoid factor levels measured because of the presence of arthralgia were found to be high. High blood anti-cyclic citrullinated peptide levels were also detected. After consultation with department of rheumatology, patient was diagnosed as RA with pulmonary involvement. Pleural effusion and nodules resolved after treatment with methylprednisolone. This case was presented to emphasize that RA should be kept in mind in differential diagnosis of bilateral pulmonary nodules and pleural effusion.
\end{abstract}

\section{INTRODUCTION}

Rheumatoid arthritis (RA) is a systemic, inflammatory, autoimmune disease with a chronic course..$^{[1]}$ Etiology is currently unknown. This polyarticular disease is often characterized by symmetric involvement of small joints; however, asymmetric involvement may occur in up to $50 \%$ of cases. ${ }^{[2]}$ Pulmonary signs and symptoms are frequent manifestations of RA.

RA is more often seen in women; however, pulmonary involvement is more often detected in men. ${ }^{[3,4]}$ Pulmonary involvement may manifest itself as pleural disease, interstitial fibrosis, nodular pulmonary disease, bronchiectasis, small airway disease, vasculitis, or pulmonary hypertension. ${ }^{[5]}$

In autopsy studies, $50 \%$ of RA patients had pleural involvement but only $10 \%$ had that pleural involvement diagnosed. ${ }^{[6]}$

As in presently described case, pulmonary involvement without much joint involvement has been reported in the literature..$^{[-1 !]}$ Present case was referred to us with initial diagnosis of metastatic lung cancer but was subsequently diagnosed as pulmonary involvement of RA. 


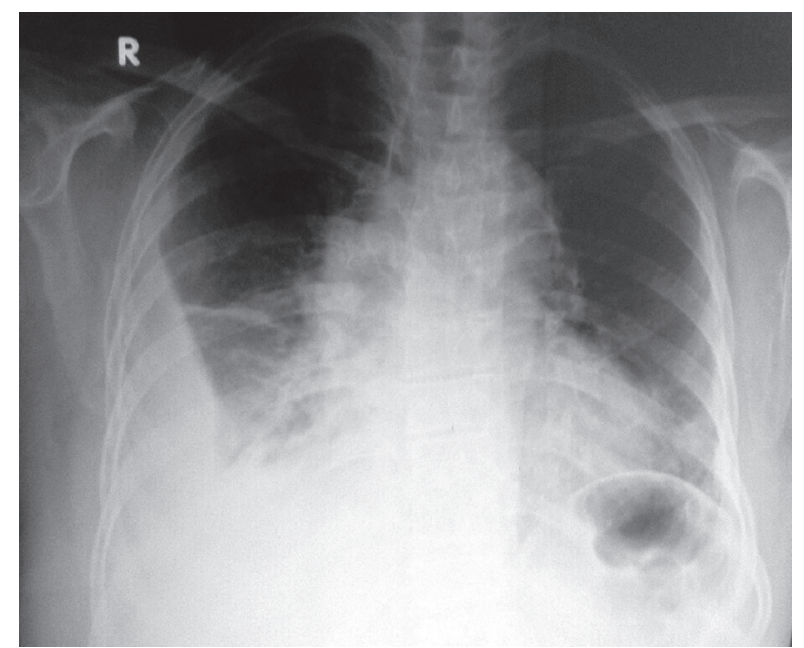

Figure 1. Posteroanterior chest X-ray.

\section{CASE REPORT}

A 52-year-old female patient presented at clinic with shortness of breath, stomach ache, and widespread joint pain. Shortness of breath had been ongoing for I year. Patient had previously been examined at another medical center and been referred to our hospital for further tests based on suspicion of metastatic lung cancer. She was born in Istanbul, and lived in Sakarya province. She was a non-smoker, a housewife, and her personal and family medical history was unremarkable.

Physical examination findings were as follows ambulatory blood pressure (ABP): $140 / 80 \mathrm{~mm} / \mathrm{Hg}$, heart rate: 88/min and rhythmic, oxygen saturation: $96 \%$ (room air); body temperature: $36.5^{\circ} \mathrm{C}$. Her general health was moderately good and she was fully conscious. Conjunctiva were pale. Respiratory system examination revealed dull sounds on percussion of basal segment of the lung. Respiratory sounds diminished on the basal segments of the right lung. Movement of joints was not restricted. Results of examination of other systems were within normal limits.
Evaluation of posteroanterior and lateral chest X-rays was consistent with pleural effusion in the right lung (Figure I). Laboratory test results were as follows: C-reactive protein (CRP) level: $76 \mathrm{mg} / \mathrm{dL}$, sedimentation rate: $110 \mathrm{~mm} / \mathrm{h}$, hemoglobin: $9.8 \mathrm{~g} / \mathrm{dL}$, mean corpuscular volume: $88.5 \mathrm{fl}$, mean corpuscular hemoglobin: 27.1 pg, platelet count: $382 \times 10^{9} \mathrm{~L}$, white blood cell count: $7.25 \times 10^{9} \mathrm{~L}$. Biochemical analyses of serum and urine yielded normal results.

Previous test results of the patient were re-evaluated. Patient had undergone gastroscopy and colonoscopy for complaints of heartburn, and chronic antral gastritis was detected. Thoracic computed tomography images obtained later demonstrated pulmonary nodules measuring $9 \times 10 \mathrm{~mm}$ in the parenchyma of both lungs, cavitating nodules in the left basal segment, and an area of pleural effusion measuring $3 \mathrm{~cm}$ at the thickest part of the hemithorax (Figures 2a-c).

Metastatic lung cancer, tuberculosis, sarcoidosis, and pulmonary involvement of RA were considered based on these findings. Acid-fast bacilli (AFB) were not detected on culture of 3 samples of patient's sputum, and tuberculin skin test produced an indurated area of $6 \mathrm{~mm}$.

Serum angiotensin-converting enzyme level, an important biomarker in diagnosis and prognosis of sarcoidosis, was within normal limits.

Thoracic ultrasound detected $44 \mathrm{~mm}$ of loculated pleural effusion in the right hemithorax.

Thoracentesis was performed and light yellow fluid was drained. Results of biochemical analysis of pleural fluid were as follows: total protein: $4.9 \mathrm{mg} / \mathrm{dL}$, lactate dehydrogenase $(\mathrm{LDH}) 1500 \mathrm{mg} / \mathrm{dL}$, albumin: $1.9 \mathrm{mg} / \mathrm{dL}$, glucose: $21 \mathrm{mg} / \mathrm{dL}$, and adenosine deaminase $36.9 \mathrm{IU} / \mathrm{L}$ (0-40). Concurrent biochemical analysis of the serum yielded following results: total protein: $7.2 \mathrm{mg} / \mathrm{dL}$, LDH: $209 \mathrm{mg} / \mathrm{dL}$, albumin: $3.5 \mathrm{mg} / \mathrm{dL}$, and glucose: $90 \mathrm{mg} / \mathrm{dL}$.
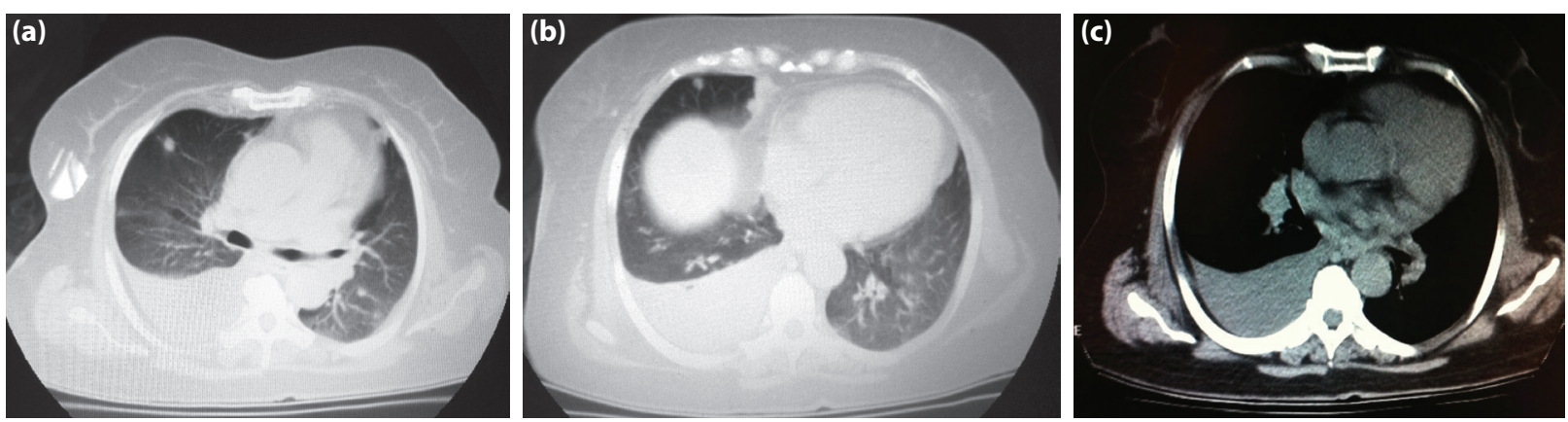

Figure 2. (a-c) Thoracic computed tomogram. 


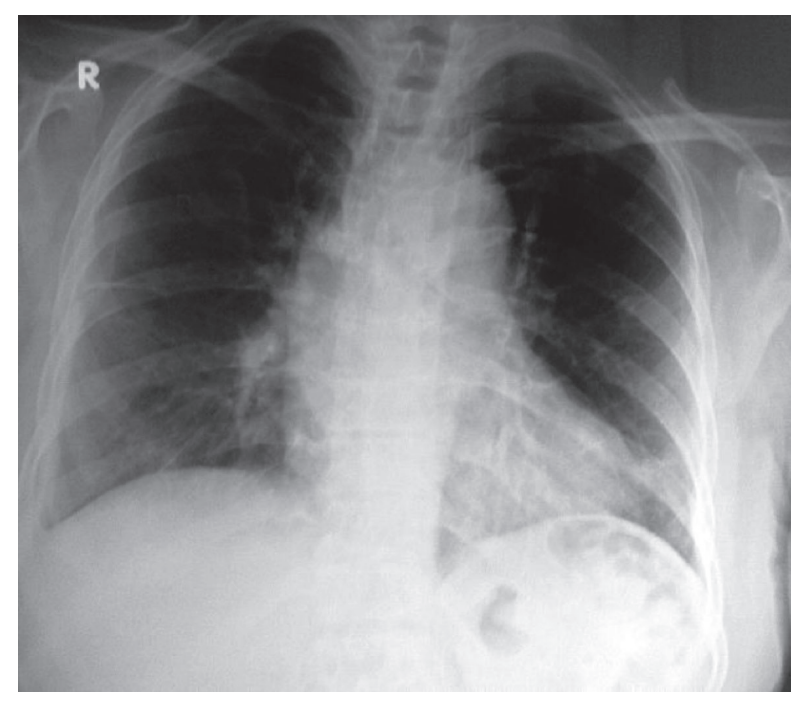

Figure 3. Posteroanterior chest X-ray.

Based on these findings, pleural fluid was determined to be exudative. Lymphocytic dominance was detected in smear test of pleural fluid. No growth of AFB or other bacteria was detected on bacteriological cultures of the pleural fluid. Cytology of the pleural fluid revealed scarce number of inflammatory cells.

Since the patient complained of widespread joint pain, serum and pleural fluid rheumatoid factor (RF) values were also determined: serum RF: II $4 \mathrm{IU} / \mathrm{mL}(0-15)$, pleural fluid RF: $95.4 \mathrm{lU} / \mathrm{mL}$ (0-15). Anti-CCP, an important biomarker in the diagnosis of RA, was elevated. The patient had consultation with the department of rheumatology, and based on diagnostic criteria of American Rheumatism Association, diagnosis of RA with pulmonary involvement was made.

In accordance with the recommendation of the rheumatologist, methylprednisolone treatment at daily dose of $20 \mathrm{mg}$ was initiated. At follow-up visit, decreased sedimentation rate and CRP level were detected. On pulmonary radiograms, pleural effusion was observed to have regressed and parenchymal nodules had disappeared (Figure 3).

Written, informed consent was obtained from the patient.

\section{DISCUSSION}

RA is a chronic inflammatory disease more frequently seen in women. It peaks during the fourth and fifth decades, and involves small joints, resulting in the formation of symmetric deformities.

Although it is not always defined clinically, pulmonary involvement is frequently seen in cases of RA, most often in men. While pleural disease is prevalent, it is generally asymptomatic. In autopsy studies, $50 \%$ of RA patients had pleural involvement but only $10 \%$ had that pleural involvement diagnosed.

When undiagnosed RA is presented with symptoms of pleural effusion, it may not be considered in the differential diagnosis, leading to unnecessary tests and waste of time. ${ }^{[10]}$

Detection of high LDH and low blood glucose levels in tests performed for pleural effusion is important to establish diagnosis. Pleural fluid with these characteristic features should suggest empyema, tuberculosis, or malignancy. In present case, cytological analysis of pleural fluid was not consistent with malignancy. Furthermore, no bacterial growth was observed on cultures of pleural fluid. Increased glucose consumption of inflammatory cells and impaired transport of glucose to inflamed pleura leads to hypoglycemia in rheumatoid pleural effusion. ${ }^{[6]}$

Parenchymal pulmonary nodules are generally asymptomatic and more frequently seen in seropositive RA patients with diffuse synovitis. Pulmonary nodules tend to be localized on the periphery. Diameter ranges from $<\mathrm{cm}$ to $6-8 \mathrm{~cm}$. Nodules can become cavitary lesions and cause pleural effusion or bronchopulmonary fistula. ${ }^{[6]}$ In cases progressing with nodules, diagnosis can sometimes be made based on invasive procedures as thoracotomy. ${ }^{[9]}$ However, considering RA in differential diagnosis enables establishment of diagnosis based on a simple serological test.

Aside from nodules, interstitial fibrosis, bronchiectasis, or small airway disease may be seen in the pulmonary parenchyma of RA patients. Respiratory function tests, $\mathrm{CT}$, and high-resolution $\mathrm{CT}$ may be used for evaluation of parenchymal involvement. In our case, bilateral parenchymal nodules were precisely evaluated using thoracic CT. Multiple parenchymal nodules and pleural effusion led us to think first of metastatic pulmonary cancer. However, the patient had joint pain, which suggested presence of RA, and high levels of pleural fluid and serum RF were detected. As a biomarker for RA, anti-CCP positivity is an extremely important diagnostic criterion.

In studies performed in our country, cases have generally been male patients; only in a study conducted by Döngel et al. was pulmonary involvement of RA detected in female patients. ${ }^{[10]}$ Demographic characteristics 
of present case were not consistent with those reported in the literature; however, RA diagnosis was made within a short time without the need for invasive procedures. Following consultation with the department of rheumatology, methylprednisolone treatment was initiated with resultant regression of patient's complaints and radiological improvement.

As is seen in this case, in undiagnosed cases of RA, clinical complaints and laboratory tests are leading tools. Though rarely seen in the literature, in female patients without diagnosis of RA, pulmonary involvement of RA coursing with pleural effusion and parenchymal nodules should be kept in mind. Especially in cases mimicking metastatic lung cancer, considering RA will enable establishment of diagnosis without the need for invasive procedures such as thoracotomy.

\section{Conflict of interest}

None declared.

\section{REFERENCES}

1. Gümüşdiş G, Doğanavşargil E. Romatoid artrit. İçinde: Gümüşdiş G, editör. Klinik romatoloji. İstanbul: Deniz Matbaasi; 1999. s. 269-79.
2. Sidhu HS, Bhatnagar G, Bhogal P, Riordan R. Imaging features of the pleuropulmonary manifestations of rheumatoid arthritis: pearls and pitfalls. J Clin Imaging Sci 2011;1:32.

3. Amital A, Shitrit D, Adir Y. The lung in rheumatoid arthritis. Presse Med 2011;40:31-48.

4. De Clerck LS. B lymphocytes and humoral immune responses in rheumatoid arthritis. Clin Rheumatol 1995;14 Suppl 2:14-8.

5. Özlü T, Metintaş M. Akciğer hastalıkları temel bilgiler. İçinde: Ylldırım Z, editör. Sistemik hastalıklarda akciğer. Ankara: Başak Matbaacilik; 2008. s. 544-5.

6. Hochberg M, Silman A. Rheumatology. In: Turesson C, Matteson E, editor. Extraarticular features and systemic involvement of rheumatoid arthritis. Ankara: Rotatip; 2011. p. 775.

7. Çimen F, Ulukavak Çiftçi T, Dulkar Dursun G. Romatoid artrite bağlı plöropulmoner tutuluma bir örnek: Romatoid plevral efüzyon (Bir Olgu Nedeniyle). Solunum Hastalıkları 2001;12:233-7.

8. Baççıŏlu A, Kalpaklıŏlu F, Güngör Ö. Bilateral plevral efüzyon sonrası tanı alan romatoid artrit olgusu. Türk Toraks Derneği, Plevra Bülteni 2014;8:4-17.

9. Yüksel C, Çelik R, Kayı Cangır A. Plevral sıvı sitolojisi ve açık akciğer biyopsisi ile tanı konulan bir romatoid artrit olgusu. Ank Üniv T F Mecmuası 2003;56:55-8.

10. Döngel I, Bayram M, Hayta E. Plevral efüzyonla prezente olan romatoid artrit (Olgu Sunumu). Cumhuriyet Med J 2012;34:500-3.

11. Borman P, Ak G, Yücel Gökçek S. Romatoid artritin başlangıç bulgusu olarak romatoid akciğer hastalığı (Vaka Sunumu). Turkish J Rheum 2002:17;174-80.

\section{Metastatik Akciğer Kanserini Taklit Eden Romatoid Artritin Akciğer Tutulumu Olgusu}

Otoimmün ve sistemik bir hastalık olan romatoid artritte (RA) akciğer tutulumu oldukça sık görülmektedir. Olgumuz elli sekiz yaşında kadın hasta, nefes darlığı, mide ve yaygın eklem ağrısı nedeniyle incelenmişti. Akciğer grafisinde iki taraflı pulmoner nodül ve plevral efüzyon saptanan hasta metastatik akciğer kanseri ön tanısı ile kliniğimize gönderildi. Laboratuvar değerlendirmesinde anemi, C-reaktif protein ve sedimentasyon yüksekliği saptandı. Torasentez yapıldı, plevral sıvı eksuda karakterindeydi. Glukoz düşük, adenozin deaminaz ve laktat dehidrogenaz yüksekti. Eklem ağrıları nedeniyle bakılan kan ve plevra romatoid faktör yüksek saptandı. Kanda bakılan anti-siklik sitrüline peptitin pozitif idi. Hasta romatoloji ile konsulte edildi, bu bulgularla RA ve akciğer tutulumu tanısı kondu. Metilprednizolon tedavisi ile plevral efüzyonu ve nodülleri kayboldu. Bu olgu iki taraflı pulmoner nodül ve plevral efüzyonun ayırııı tanısında, önceden bilinen RA tanısı olmasa dahi bu hastalığın akılda tutulması gerektiğini vurgulamak amacıyla sunuldu.

Anahtar Sözcükler: Anti-CCP; iki taraflı nodül; plevral efüzyon; romatoid artrit. 